\title{
Theofilos
}

A Nordic open access journal in Theology, Philosophy and Culture

Published by NLA University College - in partnership with Johannelund School of Theology

Available at www.theofilos.no

\section{How did sin enter the world? In dialogue with natural science}

\author{
Gunnar Innerdal \\ Associate Professor of Systematic Theology \\ NLA University College, Bergen, Norway
}

\begin{abstract}
This article suggests an answer to how sin entered the world if current natural science makes it unlikely that it happened in the way told in traditional narratives of Adam and Eve. After reviewing some current alternatives, I argue that the best available way is to understand sin as a contingent historical reality arising through a process connected to the evolutionary rise of human beings.
\end{abstract}

Keywords: Human origins, sin, the fall, historical Adam, science, hermeneutics

$\mathrm{F}$ or a systematic theology attentive to natural science, ${ }^{1}$ questions concerning the reality, origin and impact of sin are among the most complex and challenging today. ${ }^{2}$ The aim of this article is to discuss some of those questions, centering on the origin of humanity and sin, questions where Christian doctrine grounded in traditional narratives of the origin of the world, humanity and sin, are challenged by recent scientific findings. My intention is not to provide an apologetic for any specific given historical or contemporary version of Christian doctrine, but to contribute to the constructive systematic theological task of putting forth Christian faith as a coherent way to understand all of reality and human living. ${ }^{3}$ The research question can be phrased in this way: If sin is not a (metaphysical) necessity, but a historical and contingent phenomenon, and traditional narratives on sin and human origins are no longer plausible on scientific grounds; how then did sin enter the world?
I will start by discussing the plausibility problems connected to what I call traditional narratives about how sin entered the world. Then I will advance to a theological discussion where I give reasons for adherence to the first if-clause of the research question on sin as not necessary, but contingent. Lastly, after surveying some available positions on the matter, I suggest how one can imagine sin having entered the world as a contingent phenomenon within a scientifically informed Christian interpretation of reality today.

\section{The Plausibility Problems of Traditional Narratives}

For centuries, many (probably most) Christians believed in some kind of way that Adam and Eve were the concrete and historical two first human beings, a single couple from whom all later humans descend physically. 5 They were created by God in a blissful state of perfection 6 , without sin, in a world without death and evil. ' However, because of their 'fall' 8 into sin after being tempted within the created 
realm, death and decay entered the world as a consequence, and the human lineage consequently came under an inescapable bondage to $\sin .^{9}$

Versions of such traditional narratives come to expression in a range of Christian practices throughout history, such as in art, poetry, liturgy, and confessional or creedal statements, in implicit and explicit ways. Apart from the explicit historical claims such traditional narratives make, they are used in doctrinal contexts, among other things, as part of different kinds of theodicies, theories of salvation/ atonement and the freedom or bondage of the will in relation to salvation. Then again, it has significance in connection to the theology of original sin connected to (infant) baptism and the Virgin birth in many theological systems. ${ }^{10}$ They are therefore of great importance within a comprehensive theological framework.

Particularly after the Enlightenment and the rise of modern science, this kind of narrative has been heavily questioned within as well as outside the church, often for different scientific reasons. ${ }^{11}$ Charles Darwin's (1809-1882) theory of the origin of the diversity of species through natural selection from common ancestry, coupled with modern geological theories of an old universe and earth, has been and continues to be one of the central challenges raised to such a narrative. After Darwin, many other scientific insights and theories complete the picture. However, the theological and religious philosophical significance of the theory of evolution is far more nuanced and complex than a simple yes or no to Christian faith, or any other kind of faith, 12 or a yes or no to the authority or content of the Bible13.

Scientific evidence from evolutionary biology, paleontology, geology, and gene- tics question especially two notions in the traditional narrative sketched above. The first is the idea of so-called monogenesis that all human beings descend from one single couple only. Most population geneticists today hold that the human population never was below at least 10000 individuals during the transition from the evolutionary precursors to homo sapiens (anatomically modern human beings). The second is the idea of a paradisiac origin of humanity. There is no empirical evidence of human beings sometime living under conditions dramatically different from ours when it comes to the presence of suffering and futility in the world or some kind of moral perfection associated with a pre-lapsarian (pre-fallen) state.

It is important to emphasize the hypothetical nature of the reasoning in the discussion that follows. It might be that an intellectual discussion relating traditional theological narratives and current science is not necessary or relevant in many contexts and for many people. A mythical, metaphorical, or kerygmatic approach to the questions might do as good a job as a systematic treatment based on rationality, coherence and available science in many contexts. ${ }^{14}$ And further, because of the inherently hypothetical and not-yetcomplete nature of science, my suggestions should not be read as final, absolute answers to how the complete integration of theology and science must forever look from now on. They are instead to be taken as conditional propositions: if what science says on this or that point is true, and we think that science really is a pursuit of truth and can help us discern something of it, even from a theological perspective, then an answer to how to relate Christian faith to it might look like this. Performing such a task is a part of 
the Christian apologetic task of being able to give a rational account for our belief (cf. 1 Pet 3:15).

\section{Scripture Interpreted by and Interpreting Science}

Debates about Adam, evolution, and the origin of sin among Christians tend to run quickly into questions about biblical authority, hermeneutics and exegetical questions pertaining to texts in both biblical testaments. It is impossible to survey the whole range of questions, positions and arguments involved in such matters here, and I am consciously trying to avoid making the question purely an issue of biblical authority or exegetical topoi or a combination of these. My aim is rather to make a systematic theological discussion about patterns of thought in conscious interaction with the many layers of tradition, including biblical interpretation, which we are confronted with in such discussions.

Nevertheless, I will have to make some brief remarks about my Augustinian kind of thinking about the most important questions of the relationship of science and biblical interpretation that is implied in the reasoning that follows. I take these to be largely uncontroversial, although their later application might be controversial. When relating Scripture and science as part of a theological system, ${ }^{15}$ I do not think that biblical authority or specific interpretations of biblical texts is established before making a theological system on this basis, but that the theories of how to use Scripture and how it relates to scientific findings is an integral part of the theological system itself. ${ }^{16}$

In some oft-quoted passages from his treatise on The Literal Meaning of Genesis (De Genesi ad litteram) Augustine of Hippo (354-430) writes:
In matters that are obscure and far beyond our vision, even in such as we may find treated in Holy Scripture, different interpretations are sometimes possible without prejudice to the faith we have received. In such a case, we should not rush in headlong and so firmly take our stand on one side that, if further progress in the search of truth justly undermines this position, we too fall with it. That would be to battle not for the teaching of Holy Scripture but for our own, wishing its teaching to conform to ours, whereas we ought to wish ours to conform to that of Sacred Scripture. ${ }^{17}$

We can discern two basic hermeneutical principles for biblical interpretation here. The first is the awareness that there are instances where Scripture can be interpreted differently based on honest truth-seeking within other disciplines without obscuring the faith. The second is a certain caution about binding biblical interpretation too tightly to scientific evidence that is not clear enough to bear the burden, while still not refusing to try to think them together. A similar attitude is famously put in proverbial form by Holmes Rolston III: 'The religion that is married to science today will be a widow tomorrow. [...] But the religion that is divorced from science today will leave no offspring tomorrow.'18 Although any kind of relationship with contemporary science remains in some way an incomplete, hypothetical and preliminary project, there is no real alternative to trying to make such relationships.

Augustine writes further on potential conflicts between supposed interpretations of biblical texts and something like what today would be called scientific evidence: 
Usually, even a non-Christian knows something about the earth, the heavens, and the other elements of this world, about the motion and orbit of the stars and even their size and relative positions, about the predictable eclipses of the sun and moon, the cycles of the years and the seasons, about the kinds of animals [Darwinian sic!], shrubs, stones, and so forth, and this knowledge he holds to as being certain from reason and experience. Now, it is a disgraceful and dangerous thing for an infidel to hear a Christian, presumably giving the meaning of Holy Scripture, talking non-sense on these topics [...]. The shame is not so much that an ignorant individual is derided, but that people outside the household of the faith think our sacred writers held such opinions, and, to the great loss of those for whose salvation we toil, the writers of our Scripture are criticized and rejected as unlearned men. If they find a Christian mistaken in a field which they themselves know well and hear him maintaining his foolish opinions about our books, how are they going to believe those books in matters concerning the resurrection of the dead, the hope of eternal life, and the kingdom of heaven, when they think their pages are full of falsehoods on facts which they themselves have learnt from experience and the light of reason? ${ }^{19}$

What Augustine puts well here is that where clear scientific evidence, based on real empirical evidence and sound theoretical reasoning built upon them, conflicts with an interpretation of Scripture we hold to, this tension has to be relieved. 20 In most cases, this would amount to some kind of re-thinking of our interpretation of Scripture - or, by extension, the traditional teaching of the church based on such an interpretation of Scripture, as in the case of the traditional narratives referred to above. This principle does not mean that Scripture cannot correct human knowledge; there are historical examples of ideas later being recognized as good science that had their roots in theological ideas, and it is thinkable that science may learn from theology even in questions related to the ones discussed here. But when interpretations of Scripture require scientific 'non-sense' on any given topic, our first inclination should be to re-think our interpretations rather than to insist on biblical authority or inerrancy, or to engage in hopeless alternative scientific projects. ${ }^{21}$

\section{State of the Science}

The crucial question to be raised after laying out these hermeneutical principles is: What are the established scientific facts concerning the matters discussed? There are many pitfalls available for simplistic answers here, and I cannot give anything close to a complete scientific answer for my own, due both to my fields of scholarly competence as well as the number of relevant scientific sources.

Traditionally, the dividing lines between theologians and Christians of different types regarding the historicity of Adam and humanity's fall into sin has mainly been drawn between 'conservative' Christians professing a strong version of the (in some sense literal) authority and reliability of Scripture, and 'liberals' that more freely could dismiss biblical texts as collections of outdated ideas. However, in recent years, in response to clearer scientific evidence, the discussion has moved also inside 'conservative' circles, within a spectrum including Evangelicalism as well as Catholicism, where the authority of Scripture is taken more for granted. ${ }^{22}$

The Christian biologist Dennis R. 
Venema summarizes the scientific debate regarding some questions important to the discussion in this article in the following rhetorically heightened way:

many theories in science are so well established that it is highly unlikely new evidence will substantially modify them. [...] The sun is at the center of our solar system, humans evolved, and we evolved as a population. 23

Venema's claim of heliocentric certainty on this point has been subject to some debate. After a long discussion taken up by biologist Richard Buggs, Venema acknowledged that all of humankind may (mathematically) genetically stem from two sole individuals living about 700000 years ago. ${ }^{24}$ This scenario will need to involve a sudden catastrophic dip of the population of all Eurasian hominins living at the time ${ }^{25}$ to the number of two in a single generation, followed by a rapid exponential growth, and this is highly implausible, in Venema's words not even 'remotely plausible'. ${ }^{26}$ So his point stands.

Thus, in the words of Ian McFarland, '[b]y Augustine's own hermeneutical criteria' the traditional narratives mentioned above cannot stand, even if Augustine adhered to a version of them himself. ${ }^{27}$ There never was a single first human couple defining the course of the rest of the history of humanity by their actions. If this is the case - and there are good reasons to think that - we are left with a series of hermeneutical-theological and apologetic tasks. Traditional Christian doctrines and their narrative backdrop as sketched above must be thought through anew, being sensible to what is essential to them and how to continue to interpret the biblical texts behind them as authoritative and life-giving Word of God in light of our best scientific knowledge. 28

\section{The Contingency of Sin}

A possible way of responding to the plausibility problems of traditional narratives and doctrines facing current science, would be to abandon them and the doctrines they support entirely. ${ }^{29}$ This solution may threaten to undermine the Christian faith as such. The path taken here is another one: first to explore (briefly) what the significant central elements of the doctrine of $\sin$ and the origin of $\sin$ are in a systematic theological perspective, then to try to express those in a way attentive to scientific insights. I will try to make this first step by way of a summary expanding on four theses, after some initial methodical considerations.

The Christian message is first and foremost a message about Christ and God's grace given in him. It is from the vantage point of the redemption of Christ that we as Christians look backward in direction of the beginning and forward in direction of the eschaton. ${ }^{30}$ More than an account of exactly what historically went wrong in the world, where, when and in which way, the doctrine of $\sin$ is a doctrine about our current shared need of the salvation that God graciously gives in Christ's death and resurrection. The doctrine of $\sin$ is rather a consequence, the flipside of, the doctrine of redemption than a presupposition for the doctrine of redemption in Christ. ${ }^{31}$

My first thesis on central elements of the doctrine of $\sin$, is that $\sin$ is a reality. This is a very basic insight in Christian theology: we have a problem. That $\sin$ is a reality means either that sin has always been a reality, or that at some point this reality has come into existence. The almost universally shared human experience that it is something wrong in the world and human life, that things are not 
either the way they were, or should have been or shall become, suggest that the current state of the world is not simply the way things have always been and will always be. ${ }^{32}$ Sin is experienced almost universally by human beings through such phenomena as evil, deceit, violence, abuse, greed and so on, but also through anxiety or Anfechtung arising from our damaged relation to God. However, sin is not as such detectable scientifically as a problem, at least in its moral aspects. The natural scientist as scientist can say much about how things are and what people (or animals) do, but not about what they ought to do. To identify $\sin$ as $\sin$ and make human beings responsible for their lives and accountable toward God the Creator, it is necessary to activate philosophical and/or theological reasoning.

Second, all human beings are sinners and thus in total need of God's salvific interception. According to Lutheran theology (and most other Christian traditions), sin is a problem we are not able to solve ourselves on our own, either individually or corporately. However, it is probably more correct to say that we are all sinners because we all sin/are sinners, than because our fore-parent(s) did. ${ }^{33}$ The inevitability of sin in each human being's life is thus not due to a forcing necessity that can free us from responsibility or guilt, but to a kind of accumulative pressure of living as part of a collective humanity continually sinning and in a world marked by that. There is one exception to this rule, though. The basic insight in Christology that Jesus Christ was fully divine and fully man, yet without sin (cf. Hebr 4:15), shows that it is not an essential feature of humanity to be sinful even if every human being except Christ are sinners - and this holds even regardless of whether there were ever a concrete pre-historical paradisiac sinlessness of human beings.

Third, sin is our fault, not God's. This is a kind paradox given the belief in God as creator of everything, thus rejecting forthright metaphysical dualism. Is it expressed as such e.g. in the Augsburg Confession art. XIX 'although God does create and preserve nature, yet the cause of sin is the will of the wicked' (emphasis mine). God created everything but is not the cause of sin! Dietrich Bonhoeffer puts this point strikingly:

The Bible does not seek to impart information about the origin of evil but to witness to its character as guilt and as the unending burden that humankind bears. [..] It will [..] never be possible simply to blame the devil who has led one astray; instead this same devil will always be precisely in the place where I, as God's creature, in God's world, ought to have been living and did not wish to live. [..] [It is] just as impossible to accuse creation of being imperfect and to blame it for my evil. The guilt is mine alone. 34

Fourth, a fundamental Christian insight regarding $\sin$ (and its associates suffering, death and decay) is that it does or did not have to be this way. In every concrete act of sinning as well as in all humankind having become sinners in the stronger sense, in our current lives as well as in the lives of our forebearers, it is possible to imagine not sinning. This implies that God is not/was not forced to use the cruelties of the evolutionary process as his only option for creating something good (in this sense our sinful world is not the best possible world, but perhaps the best possible world with us in it ${ }^{35}$ ). As a Christian endorsing the strict scientific theory of evolution and its empirical basis, I still 
think it is important that we do not conflate the concrete evolutionary process and the concrete sinful human history in this world with God's original will or his only option for creation. ${ }^{36}$ Instead of viewing evolution as God's ultimate intention, one should view evolution as God's way of sustaining and by novelty make all of creation flourishing under present conditions, including human sin. It is possible to imagine an evolutionary process with both more or less of the dark sides of suffering, evil and death, but that would be another world.

\section{How Sin Entered the World}

If $\sin$ is to be conceived as a reality that is not necessary and cannot be blamed on God, it seems that in some sense sin must have 'entered' the world at some point or in some way. The expression comes from Paul in Rom 5:12, using the word eiserkhomai, to come into. ${ }^{37}$ The phrase has a similar kind of paradoxicality to it as the snake in the Garden story (where did it come from?), for was sin in any sense or anywhere before it entered the world, which seems to follow from the spatial expression in the metaphor? Perhaps a better term would be to say that sin arose within the world, but for the sake of familiarity I will stick to the traditional term. Biblical theology as well as anthropological and philosophical considerations strongly suggest that this entrance of $\sin$ is in some way closely connected to the rise of humankind.

I will start my suggestive discussion about how this can be imagined in a scientifically informed Christian faith today by sketching out four types of alternatives currently trying to respond to the plausibility problems of the traditional narratives outlined above while being attentive to current natural scientific knowledge. ${ }^{38}$
They are all closely connected to the question of the historicity of the first sinners in traditional narratives, Adam and Eve, and their scientific plausibility.

\section{Current Alternatives to Traditional Narratives}

A first type of views is those that champion more or less purely existential interpretations of the Genesis narrative. The story of the disobedience of Adam and Eve is primarily exemplary or typological, expressing common elements of the human condition. This type of views does often not in a strong sense answer the question in the way I have framed it here, but elements of such views can be interesting alternatives for integration in a nuanced position, because they often contain insightful perspectives on the current situation of human beings as sinners.

According to these types of views, Adam and Eve are not historical individuals, and the 'fall' into sin is not an event in history with a before and after in the normal sense, but some kind of mythological or figurative narration of the common human condition. An oft-quoted representative of this view is Søren Kierkegaard, who emphasized that the condition present at Adam's fall into sin is not radically different from the condition when we all make that same fall. ${ }^{39}$ Dietrich Bonhoeffer also comes close to such a position because of his insistence on the inaccessibility of our origins and the fall. 40

A weakness of these types of views is that they might easily be taken to imply that $\sin$ is just the way things are and always have been (thus perhaps compromising creation's original goodness and the contingency of sin), since proponents often refuse to take a stand on the question of how sin entered the world. ${ }^{41}$ 
A second type, and a more full-fledged attempt to answer my framing of the question, is views where an attempt is made to uphold the idea of only two concrete individuals as the genetic origin of our species. ${ }^{42}$ But to avoid inconsistency with genetics, this couple is placed way back in history compared to traditional readings of the historical context of Genesis, which are based on e.g. traditional biblical chronologies or the presence of agriculture in the story. This type of view is, as noted above, scientifically possible, but highly implausible. ${ }^{43}$ The Garden (in some kind of figurative sense) story of Adam and Eve, according to this type, stands for the first two human beings, which must be taken in a loose, homininlike sense, sometimes including Neanderthals and Denisovians and other of our human-like relatives, falling into sin in a very distant past. Such versions can be found in circles affinitive to or affirming Intelligent Design-thinking. ${ }^{44}$

This type of solution raises as many questions as it solves regarding human uniqueness and sinfulness. Besides being scientifically implausible, bordering on impossible, this kind of solution is also highly arbitrary in exegetical and hermeneutical perspectives. It is difficult to see, for example, why the notion of a historical ancestor couple is the only point in the story recorded in Genesis that should be taken literally, while its historical and geographical context, as well as what the text says about the origin of other animals or the presence of agriculture, should not. This kind of views can be excluded from further discussion here as a possible but currently not even remotely plausible alternative.

A third type of views affirms some kind of fairly recent ${ }^{45}$ historicity present in the Genesis narrative about Adam and
Eve. 46 This can happen in a way taking them to be two concrete historical persons, or by making them representatives of the human race, either as individuals or a group.

A first subcategory affirms that the Adam and Eve of Genesis were two concrete historical individuals in the recent past who are parents (in genealogical sense) of all human beings made in the image of God. However, to be reconcilable to genetic science, this couple is not conceived as the sole genetic progenitors of all humankind. This is a deviation from what I have called traditional narratives since it does not uphold monogenism. This couple's universal parenthood of modern humans came through gradual mingling with other creatures existing at the time. The transition from pre-human ancestors to humans made in the image of God happened through a special intervention by God, either through a special spiritual endowment of already existing creatures, or a new miraculous creation of two individuals with similar genetic attributes as fellow human-like creatures. The Garden story recounts a rebellion against God that happened with the first human beings in this sense, which later spread to all humankind.

A classical proponent of such a view is theologian John Stott, using the term homo divinus ('divine' man) for the first human beings created in the image of God, then falling into sin. ${ }^{47}$ The Christian scientist S. Joshua Swamidass has recently strongly championed the scientific possibility of this kind of view, emphasizing that it is genetically possible that all current human beings, as well as all human beings alive at $\mathrm{AD} 1$, share a sole couple living recently in the Middle East as genealogical (not genetic) ancestors. ${ }^{48}$ If so, those were not our only (or first) ${ }^{49}$ 
genetic ancestors, and interbred with other biologically similar creatures at the time, which Swamidass calls 'people outside the Garden'50, who had evolved through common descent (cf. the old question about Cain's wife, Gen 4:17). Through the generations, all living human beings through this original couple's lineage might have had a share both in their creation in the image of God and their fall into sin and its consequences. C. John ('Jack') Collins comes close to this view from another angle (without stressing the insights from genetic/genealogical science), saying that Adam and Eve where representatives of the initial human population, their 'father/king and mother/queen', and stressing their universal parenthood for later humanity. 51

In another subcategory of type three we find theologians insisting on the historicity or event-character of the fall all the while avoiding the claim that Adam and Eve were two concrete historical human persons. Instead, it is said that the Genesis story refers to real historical events, but narrated in a figurative, not literal sense, as is also the case with Collins. Thus, Adam and Eve can be taken to stand for an initial group of human beings representing them all vis-à-vis God. Some authors, especially in the reformed tradition, apply the concept of covenant to this kind of representation idea, borrowing from OT biblical theology and a certain reading of Hos 6:7.52 A recent example of this is James K. A. Smith, who argues that there might have been an initial group of hominins 'elected' by God into a covenant, but his solution borders on type four because he places the event further back in time. ${ }^{53}$

A fourth type of views claims that sin entered the world through a gradual process connected to the rise of humankind as a population or certain characteristics of humanity, such as consciousness or ability for moral reflection or a special relation to God, and not through individuals (or groups) acting in a singular event. There have probably been suffering and death and natural behavior close to evil in the proper sense involved in natural processes long before human beings stepped on the earth, but sin in the proper sense committed by someone accountable for it arose when human beings became evolutionary capable of sinning in that sense. The South-African theologian Ernst M. Conradie is a current champion of such a view articulated into some detail. 54

The most important strength of this kind of solution is that it requires little adjustment to standard scientific accounts of the history of humanity in order to integrate science and biblical concerns. It can also be argued that it is based on a more refined biblical hermeneutic, even if it raises important questions about how to understand apostolic authority and the literal sense of apostolic texts of the NT in some theological milieus. Its main weakness in relation to traditional narratives is that the event-character of the 'fall' is weakened.

\section{Discussion of the Most Promising Types}

Views of both the third and the fourth type might deserve a closer look as they are both scientifically and exegetically possible and to some extent plausible. Type three usually avoids scientific nonsense in the hermeneutical sense of Augustine, but remains very hypothetical at the scientific level; there is no evidence against it, but there is also no scientific data suggesting that this really was the case, while there is scientific data and 
plausible interpretations of them that at least implies that it was not the case. In order to make the idea come up scientifically at all, a certain historical-literally minded reading and hermeneutic of Scripture must be presupposed, 55 so the weight of support for this argument must lie on the theological side.

When it comes to biblical hermeneutics, type three has an easier task in integrating New Testament material about Adam in the framework of a theology strongly emphasizing apostolic authority. There are passages in which both Paul, Jesus and the author of the Gospel of Luke seems to talk of Adam in a sense close to what we today would probably call a historical human person. ${ }^{56}$ But in the exegesis of Genesis and other relevant OT texts things are more complex. Why, for example, must the claim that the first human being Adam was created 'from dust' and given 'breath of life' (Gen 2:7) indicate a kind of special creation or intervention concerning the creation of human beings in evolutionary perspective, while the same terms applied to other animals (Gen 1:20;2:19) are not taken at the same level? And how is it to be explained in this kind of scenario that the narrative places the creation of animals chronologically after the creation of the first human being? Emphasis on a literal creation of Adam and Eve also seems to be little consistent with far-spread nonliteral interpretation of other literal aspects of the text. Few Adam and Eve supporters insist e.g. on the historical character of the walking and talking snake (no fossil evidence of such a species at the supposed time), the geographical location of the Garden (the rivers and lands of 2:11-14; and the location of the tree of life and the flaming sword, or their continued existence, 3:24) and the impli- cit presence of Adam's mother and father in the narrative (2:24).

Type three can also have some difficulties in its theological implications. In this model, the historical transition into humans in the full sense must presuppose some kind of miracle or special divine intervention. While this is a possibility, it is not clear why that must follow from a reading of Genesis that is not literal in a strong sense (as shown above). Invoking of miracles as an explanation of (partially) natural processes ought rather to happen when relatively unambiguous historical witness claims that a miracle happened, as in the case e.g. of the resurrection of Jesus. The literary characteristics of Gen 2-3 are much more ambiguous in this sense. And if they necessarily must be interpreted as describing such a miracle, it is strange that it did not leave any kind of scientifically detectable traces, especially if Adam was the kind of pre-lapsarian super-human he is often conceived as in traditional narratives. ${ }^{57}$

I think it is a fair reading of Genesis 1-2 that the primary miracle there is creation as such (ex nibilo and by the power of the word of God), not that human beings are created in a basically different or more direct way than other living creatures. An important motivation for claiming the historicity of Adam and Eve in this way is often that it provides a secure grounding for the dignity and rights of all human beings, as well as our common culpability for original $\sin$ by some kind of inheritance. However, a problem is that the model (at least in subcategory one versions) seems to be suggesting that genealogical descent is relevant to who has a share in this kind of humanity or sinfulness, and the door can be left open for very unpleasant consequences in questions relating to racism and a naïve biological understanding of 
sin. ${ }^{58} \mathrm{~A}$ better approach concerning human dignity, as has been convincingly argued by Monika Hellwig and Daryl P. Domning, is to underscore that 'the boundary that marks the distinction between the human and other animals need not be sharp to be real and consequential.' 59 It does not require miraculous divine intervention.

It is also a matter of discussion whether type three resonates more easily with the traditional narratives sketched at the beginning of this article than type four. The first human couple becomes so in a very revised sense, perhaps not being able to bear the theological implications that the traditional narrative used to carry. Swamidass' genealogical hypothesis clearly affirms that it scientifically requires a substantial population of 'biological humans' outside the Garden. The biblical texts alluded to in order to justify this claim can in my view hardly be taken to refer to such a population, talking of Nephilim, giants and sons of God (Gen 6:1-4) - not anything close to humans of the same biological makeup as Adam and Eve. Cain's wife and the inhabitants of cities outside the Garden is a better basis, but the narrative of Genesis still claims quite straightforwardly that there was no human being before the creation of Adam (Gen 2:5).60 Swamidass' use of the term monogenism also becomes quite contraintuitive. The 'people outside the Garden' who according to evolutionary science made the proposed 'monogenism revised' of a genealogical Adam and Eve possible, did not themselves rise through monogenism.

The traditional connection between human sin, suffering and physical death (e.g. the pre-lapsarian state) is also lost in type three (as in all the other types). Thus, it might seem that the hermeneutic strength of type three regards only hermeneutics of biblical literacy and authority when they are applied selectively and does not besides that have notably more theological explanatory power than type four. My tentative conclusion regarding type three is that it is scientifically possible, but scientifically implausible (or, scientifically strictly not assessible). The theological support for the view, however, is not strong enough to make it very attractive as a comprehensive alternative. It is in a fundamental way arbitrary in what it takes for granted as needing to be interpreted literally in the Scriptures.

I have thus ended up assessing types one through three as not plausible in different degrees. That does not imply that type four is totally convincing or logically necessary, but it seems to be the best possible explanation of the data I am currently aware of from science and theology.61 I will therefore end by a suggestive further articulation of such a view, in dialogue with some central possible objections.

Ernst M. Conradie articulates an attractive version of type four, the entrance of sin to the world as a gradual process connected to the evolutionary rise of humankind, in Redeeming Sin (2017).62 The aim of the book is to retrieve Christian sintalk in the discourse concerning current environmental problems, but he also goes quite far in discussing what has went wrong in the world. A central notion in his proposal is the distinction between different levels of complexity in the evolutionary process and their connection to the questions discussed here. He speaks of 'bifurcations' that happened both before, during and after the transition into human beings:

At each level of emerging complexity in (human) evolution, what may 
retrospectively be considered to be 'good' (reaching maturity) or 'bad' (undermining a process of maturation) is not pre-determined. Bifurcation (in the sense of things going 'right' or 'wrong') is possible but not necessary at each level of complexity in an ongoing process apparently aimed at reaching relative maturity appropriate to that level. Bifurcation at a given level of complexity will set parameters for any further levels of complexity but does not determine further bifurcations. Only at some levels of complexity such bifurcation may, retrospectively, be judged in economic, moral, religious or theological terms. ${ }^{63}$

The concept of maturation is drawn from the theology of the Church Father Irenaeus of Lyon (c. 125-c. 203) and theologians following him. ${ }^{64} \mathrm{He}$ thought that the first human pair in paradise was created with a childlike innocence, and was intended to grow. This is a notion that can fit very well with modern evolutionary cosmology. Furthermore, by emphasizing the relative 'freedom' of each level of complexity even if they in a certain sense follow upon and determine another, Conradie also opens the possibility of maintaining the traditional Augustinian notion that human beings at some time were able not to sin (posse non peccare). In Conradie's version this means only minimally that they were never forced into sinning by some kind of necessity; it does not necessarily mean that human beings at some point were in a very different and less vulnerable position with respect to sin. The only principal difference between the first human sinner(s) and later generations of sinners would be the difference of not having (accountable) sinners as biological and sociological parents, however much or little that entails.
A gradual view of how sin entered the world needs to be accompanied by a nuanced view of the close connections between human beings and our pre-human predecessors when it comes to sinful behavior. As pointed out by Michael J. Chapman, 'humans are predisposed to misbehaviors (..) because of our evolutionary history'.65 Human beings always have been (from the transitional phase[s] into our species until now) genetically disposed for sinning through their evolutionary heritage. This fact, however, does not mean that human beings are not accountable for sin, from our origins until now, because when human beings became aware of what they were doing, and that they could refrain from doing wrong or evil things or damaging their relationship with God, they were accountable spiritual beings and responsible moral agents (cf. the fall as knowledge of good and evil in the Genesis narrative). Thus, this evolutionary heritage is perhaps not a greater problem for avoiding blaming God for sin than traditional versions underscoring $\sin$ as a possibility in the pre-lapsarian state. The snake was in the Garden, after all. Together with this notion of accountability, it is plausible to connect the rise of human sin within the world with higher levels of complexity concerning consciousness of self, of the human other and his/her dignity, and of God as benevolent creator and the human relation to God. 66

There are pointers in the direction of this almost purely hypothetical character of the 'pre-lapsarian' state of posse non peccare both in the biblical narrative and in pre-enlightenment and pre-Darwin theological reflection. In the Genesis narrative, there is nothing notable happening between the creation of man and his woman before they both disobey the only 
prohibition he ever received. Adam wasn't very long in Paradise! An example is the Church Father Maximus the Confessor (c. 580-662), who was a sharp critic of Origen's theory of a pre-creational fall with creation itself as a kind of consequence of this fall. ${ }^{67}$ Thus Maximus emphasized that the fall into sin happened after God had created everything, inside the created realm. However, he still says that man fell when he was created (hama to ginesthai - 'together with the act of coming into existence'), as to underscore that the pre-lapsarian state is of a more principal and hypothetical kind than a period of notable duration. 68

An important question facing type four views of the story about how $\sin$ began is how it resonates with the eventcharacter and thus the historical contingency of the fall. As Cavanaugh and Smith points out, it may seem to be crucial for traditional doctrine that the nature of the Fall is 'historical' or 'event-ish' ${ }^{69}$ Thomas A. Noble, for example, strongly argues that the Fall must be 'an event within the created realm', adding that it must be a single event. ${ }^{70}$ For reasons of upholding the contingency of sin I fully appreciate the notion inherent in the first point that sin happened within creation, but I think it is worth asking with Daryl P. Domning whether the second is not an 'unexamined assumption' left over from traditional narratives that must not necessarily follow from a reading of the biblical texts and a dogmatics of sin as contingent attentive to natural science. ${ }^{71}$

A short visit to Paul Ricoeur can perhaps help here. He speaks of an 'extreme contraction of the origin of evil into one point' in the 'Adamic' myth' (we could add, also in traditional narratives based on it), that 'emphasizes the irrationality of that cleavage.' But it is still narratively spread out into a 'drama which takes time', thus suggesting that the point is not the duration of the 'event' as short or long. ${ }^{72}$ Thus, I suggest, human beings started to sin when they became evolutionary capable of doing so, and has continued doing so from that time on. ${ }^{73}$ The duration or historical frequency (or how many times it happened) of the event(s) is strictly irrelevant to the doctrine of sin, and there are good reasons to think that we will never be able to describe exactly when, how or how many times it happened. What we know is that it happened to human beings and affects us all.

Gregory A. Peterson argues that '[i]n an evolutionary framework, it might be more accurate to speak not of "the fall' but of falling,' thus resonating well with my argument so far on the gradual entrance of sin. However, he also adds that this falling in a comprehensive picture could not be seen only as a falling down (from some original heights) but also as a falling up. The bifurcations into new levels of complexity in human evolution are always double edged, while opening possibilities of heightened goodness, they may also be used to maximize evil. So there is a certain risk and fragility involved in the special attributes of human beings - the higher you are climbing, the farther down might you fall. ${ }^{74}$ This is a dynamic well recognizable from use and misuse of modern technology and globalization. This way of putting it resonates well both with an Irenean model of maturation and the Genesis story, where the Fall leads to gain as well as pain, heightened knowledge as well as expulsion from the Garden by the grace of God.

A last objection to the view of the entrance of sin into the world as a gradual process to be treated only briefly here (relative to its complexity and contro- 
versy) is the one from biblical (apostolic) authority. What about the claims of Paul and other NT passages concerning Adam? Do they not presuppose a historical, personal Adam and his single Fall? How then could we reject that? My first response to such questions is to take a step back and reflect briefly on the level of acuteness of the problem. There is currently much contextual emotional pressure and in some circles ecclesial constraints connected to the question of the historical Adam as case of biblical authority, but it can be argued that there are similar cases concerning biblical authority which is not felt as having the same kind of urgency. Different strands of Christians today are often well accustomed to think that passages in the OT are accommodated to the language and system of knowledge current at the time. E.g. the Earth is not flat, does not rest on pillars, and there is no underworld beneath our feet, even though some biblical texts seem to claim such things. ${ }^{75}$ There is no good reason to hold that the case is totally different in the NT. For example, almost no-one holds the view today that evil spiritual powers rest literally in the 'air' or the atmosphere closely above the earth (gr. aer, see Eph. $2: 2$ ), that the seed of the mustard tree is literally the smallest of all seeds (see Mark 4:31, where Jesus seems to be claiming that), or that nature itself teaches that long hair is shameful to a man (1 Cor 11:14). These are all questions where the interpretation and application of Scripture is usually informed by science or common sense in a quite straightforward way, without suggesting that it thereby undermines apostolic authority. ${ }^{76}$ Thus, we should at least be open to the possibility that Paul and other NT authors express ideas that are of theological relevance together with 'facts' that are not viewed as facts by modern readers.

When it comes to evolutionary biology and human origins, as provocatively put by Scot McKnight, Paul 'could not have and therefore did not know better.'77 The reason is that all human communication happens within a cultural context, or put more theoretically: every true proposition must be placed in a theoretical framework. ${ }^{78}$ It is fully possible, however, that propositions expressed within a theoretical framework including certain scientific or other knowledge from a given cultural position in space and time, can be true even in other theoretical frameworks. In the case of Jesus, this kind of inculturation to the cultural theoretical framework of his day (e.g. concerning a global Noahflood, or the authorship of OT texts) can be seen Christologically as following from his full humanity. It is impossible to be fully human separated from any concrete, historical and cultural context. Whether this was something he in his divine-human person was aware of, merely accommodating what he said to his hearers, we will never now. In the history of ideas, one cannot expect people to answer questions that was not yet raised, or to adjust their theological reasoning to scientific insights yet not gained. Yet one does not therefore need to conclude that they were completely wrong, for relative to their theoretical framework their reasoning might have been all good. The question of whether Paul believed in a historical Adam is thus perhaps not the most important one. He did probably believe in Adam in a more 'historical' sense than most people today, but the distinctions between historical, figurative, mythological etc. approaches to primeval history in the modern sense was not known to him, because at the time there was little scientific knowledge available 
about this part of history. A central task would therefore be to analyze not only the literal content of apostolic sayings, but also their meaning and motivation, and how they connect to other notions, even in the case of Adam and the fall.

McKnight, citing Paul Achtemeier, points out some important aspects of Paul's reasoning regarding Adam:

'The universality of human mortality is Paul's empirical proof of the universality of human sin.' That is, Paul knows from Genesis that sin leads to death, and since all die, he knows that all $\sin .79$

If that is the case, the historicity of Adam is not a strict necessity for Paul's articulation of the meaning of the redemption given in Christ. The meaning of the figure of Adam in Paul's reasoning is that all human beings are mortal sinners in need of redemption. A contemporary account of a gradual entrance of sin into the world could ground that concern just as well.

We can thus think that Paul and other NT author express their views - views with real theological implications that should be integrated into contemporary systematic theology - within ancient theoretical frameworks containing notions that we today have better knowledge of in e.g. scientific or historical terms. I suggest that Paul would have expressed himself in other ways concerning Adam today, within a theoretical framework suitable for communication of the Gospel in our world, including the best available contemporary knowledge of evolutionary biology and genetic science, as well as the historical context of Genesis. Regrettably, however, we will never be able to ask him.

The question in the end is perhaps: what is the greater problem for our theo- logical systems? That minor adjustments are made to traditional notions in some corners about apostolic authority, cultural frameworks and historicity, or that the thinking about the hermeneutical relation between science and theology must be changed by claiming that Paul or other NT writers forces us to hold views that are at the end of the day highly implausible in light of the best of contemporary science? ${ }^{80}$ I think that the first alternative is the most viable in the long run, because it is most in accordance with my hermeneutical principles building on Augustine, and also the most faithful to Scripture, bringing Scripture into a real conversation with us and everything we do, know, think and believe.

\section{Conclusion}

In this article, I have surveyed different attempts to answer the question of how sin entered the world, attentive to current natural scientific knowledge of human origins. I first noted some plausibility problems for traditional narratives of the fall and original sin facing modern science, most recently (population) genetics, which rejects the possibility of monogenesis in the traditional sense and questions the reality of a pre-lapsarian state. Then I noted four central elements of the doctrine of sin that needs to be taken into account when trying to re-think traditional narratives in a contemporary systematic theology that faithfully reworks the tradition. These included that $\sin$ is a reality, that all human beings are sinners, that $\sin$ is our fault, not God's, and that things did not or do not have to be this way. By way of summary: sin is a contingent, created reality that is not metaphysically or otherwise necessary.

Then I described four currently proposed types of views attempting to describe 
human origins and the entry of sin to the world. A first type refuses the question by avoiding answering it, making instead an existential interpretation of the Genesis narrative. A second type places the first human couple and their 'fall' way back in hominin time. A third type suggests that Adam and Eve in some sense was historical human beings, created de novo or in some way endowed with a new relationship with God, before falling in some kind of historical event. They may have interbred with other creatures of the time, and thus become the genealogical (but not genetic) ancestors of all later human beings. There are also group versions and more figurative versions of this type, where Adam and Eve are representatives or stands for a group of early human beings. The fourth type is to view the entrance of sin into the world as a gradual process closely connected to the evolutionary rise of humankind. After discus- sion of type one through three concluding that they are all in some degree implausible, I articulated a version of type four drawing on the work of Ernest M. Conradie, and in dialogue with some possible important objections to this way of thinking.

In order to gain a more comprehensive understanding of the doctrine of $\sin$ attentive to natural science and other relevant human knowledge, other questions that could not be handled here must be pursued as well. Among them are questions about what kind of problem sin is, what our common status as sinners entails, the relation between individual and collective aspects of the doctrine, and traditional ecumenical disagreements on the understanding of sin. The challenges raised by natural science may be an impetus to further work on the doctrine of sin also regarding such questions. ${ }^{81}$

\footnotetext{
Notes

${ }^{1}$ In my understanding this excludes young-earth creationist views from discussion in this article, because I find them at odds with a great range of concrete empirically based, sound natural scientific reasoning in many disciplines.

2 Wolfhart Pannenberg says: 'No other theme in Christian anthropology has been so obscured for us today than that of sin and our approach to it', (the first sentence under the heading ' $\mathbb{\$} 3$. Sin and Original Sin'), Systematic Theology, vol. 2 (Grand Rapids: Eerdmans/Edinburgh: T\&T Clark, 1994), 231. Pannenberg is not only concerned with science-theology issues, but that is an important part of the complex picture he refers to.

3 As I have shown in Gunnar Innerdal, 'Troens troverdighet. En drøfting av apologetikkens oppgave og plass i systematisk teologi', Teologisk Tidsskrift 1, no. 4 (2012): 419-436, this can be viewed as undertaking an apologetic task, or as having an apologetic concern within systematic theology.

4 This question is highly relevant to the doctrine of original sin (as some kind of inheritance or consequence of the origin of $\sin$ ), but the content of that particular doctrine will not be elaborated on in this article.

5 See e.g. C. John Collins, Reading Genesis Well: Navigating History, Poetry, Science, and Truth in Genesis 1-11 (Grand Rapids: Zondervan, 2018), 232. Cf. Stephen Greenblatt, The Rise and Fall of Adam and Eve (London: The Bodley Head - Penguin Random House), 2-3; and first paragraph of Rebecca Randall, 'What If We Don't Have to Choose Between Evolution and Adam and Eve?' Christianity Today Jan 30, 2020, see https://www.christianitytoday.com/ct/2020/january-web-only/genealogical-adam-eve-evolution-joshua-swamidass.html. Joshua S. Swamidass himself does not include the intuitive sense of monogenism in his version of the traditional narrative, claiming he has most of theological history on his side. Joshua S. Swamidass, The Genealogical Adam and Eve: The Surprising Science of Universal Ancestry (Downers Grove: IVP Academic, 2019), 5 et al. I think he is wrong, but it is not possible to establish that statistically or otherwise in this context, except through the glimpses of historical examples given.

6 How perfect this perfection was is a matter of dispute. The traditional theological consensus is that this original state was perfect at least in the sense of much better than the world we experience now, and without any kind of specific lack or content that questioned it from being 'very good' (Gen 1:31).

7 Swamidass, again, alters the traditional narrative by placing sinlessness and the possibility of immortality within a Garden in the midst of a world with wrongdoing (perhaps not sin in the strong sense) and (at least physical) death present. Genealogical Adam and Eve, 178 Table 14.1, 205 et al.
} 
8 I have put the word 'fall' in quotation marks just to underscore its utterly metaphorical sense (in the traditional western-Augustinian use as well as in theology standing in dialogue with modern science). See e.g. Ernst M. Conradie, Reedeming Sin: Social Diagnostics Amid Ecological Destruction (Lanham: Lexington Books, 2017) 136; cf. also Collins, Reading Genesis Well, 177; 227-233.

9 A similar summary of the different aspects included in the concept historical Adam is made by Scot McKnight in Dennis R. Venema and Scot McKnight, Adam and the Genome: Reading Scripture after Genetic Science. (Grand Rapids, Brazos Press, 2017), 107-108. Note that my summary is by purpose made without making explicit claims that presuppose an in a strong sense literal interpretation of the texts concerning the creation of man (or other creatures) and the Eden story in Gen 1-3. I have also put the word narrative in plural ('traditional narratives') to make explicit that I do not refer to any single very particular view on each of the issues or notions involved. Instead, I am referring to a type of views that can be reasonably thought of as belonging to a group because they agree to a certain degree on the most important things.

10 Some important examples include The 1529 Augsburg Confession art. II on original sin and its transmission from Adam; The 1577 Formula of Concord art. II on the status of the human will before and after the fall; The 1993 Catechism of the Catholic Church \$ 391, 391 \& 399 on Adam and Eve as our 'first parents'; and the canons of the 'Augustinian' 418 Council (or Synod) of Carthage on bodily death as a consequence of $\sin$.

11 They have of course also been questioned for other reasons and at earlier times, but that is not my concern here. For suggestions in other fields, se Tatha Wiley, Original Sin: Origins, Developments, Contemporary Meanings (New York: Paulist Press, 2002), 206-207. A through account of some of the problems at the intersection of traditional narratives and contemporary science can be found in John Schneider, 'The Fall of Augustinian Adam: Original Fragility and Supralapsarian Purpose', Zygon 47, 1 (2012): 949-969.

12 For a through account of this point, see Conor Cunningham, Darwin's Pious Idea: Why the Ultra-Darwinists and Creationists Both Get It Wrong (Grand Rapids/Cambridge: Eerdmans, 2011). 13 See e.g. Peter C. Bouteneff, Beginnings: Ancient Christian Readings of the Biblical Creation Narratives (Grand Rapids: Baker Academic, 2008).

14 Cf. e.g. how Dietrich Bonhoeffer repeatedly stresses that our position in the middle (of an already sinful world) makes it impossible (and perhaps not desirable) for us to access the beginning, in Creation and Fall.

15 The word system is here used in a loose sense, as what is the result of having done systematic theology, roughly equivalent to comprehensive position.

16 Cf. Innerdal, Gunnar, 'Bibelsynets systematisk-teologiske sammenheng.' Theofilos Supplement no. 1 (2015): 20-32, and 'Troens troverdighet', 425-426.

17 (St.) Augustine, The Literal Meaning of Genesis, 18,37. Available among others in Ancient Christian Writers, vol. 41. Translated and annotated by John Hammond Taylor, S.J. (New York: Paulist Press, 1982). 18 Holmes Rolston III, Science and Religion: A Critical Survey (Philadelphia and London: Templeton Foundation Press, 2006), p. ix.

19 (St.) Augustine, The Literal Meaning of Genesis, 19,39.

20 A similar stating of this point: 'If indeed [the 'books' of] nature and Scripture have the same author, as Christians affirm, then there cannot, ultimately, be any disagreement between what we 'read' in one book and what we read in the other. The problem, of course, is that our 'reading' of either book is not perfect. Science does not yet have a full picture of many aspects of the natural world. Similarly, our exegesis and hermeneutics are not infallible. As a result, there may appear to be conflict between science and Scripture, and it may take a long time to sort out apparent disagreements as we wait for improvements in science and theology.' Venema in Adam and the Genome, 8. Cf. the remarks on 'all truth as God's truth' in the introduction to Douglas J. Moo, 'The Type of the One to Come: Adam in Paul's Theology', lecture as part of Adam and the Fall, Creation Project at Henry Center. Available at https://henrycenter.tiu.edu/resource/the-type-ofthe-one-to-come-adam-in-pauls-theology/ (accessedible 05.09.2019)

21 For a more thorough discussion of some points made in this paragraph, see Peter Harrison, 'Is ScienceReligion Conflict Always a Bad Thing?: Augustinian Reflections on Christianity and Evolution,' in in Evolution and the Fall, ed. James K. A. Smith and William T. Cavanaugh (Grand Rapids: Eerdmans, 2017). 22 Cf. many of the works referred to and their pre-history, as well as, e.g. the conference Adam, the Fall, \& the Goodness of God, at Henry Center March 22-23, 2019. To be noted in passing is that the later generations of mainstream Lutheran theologians has not regarded these questions as so significant as in the current discussion, having its center of gravity within Evangelicalism in the US. A recent example of this attitude can be found in Eva-Lotta Grantén, Utanför Paradiset: Arvsyndsläran i nutida luthersk teologi och etik (Stockholm: Verbum, 2013), esp. 44-47, where Grantén without further discussion goes far in rejecting any kind of historicity connected to the Genesis account, relying on the German biblical scholar Claus Westermann. See also Philip Hefner, 'Biological Perspectives on Fall and Original Sin', Zygon 28, 1 (1993): 77-101. In my judgment, this difference is mainly due to different dominant frameworks concerning how to relate creation and redemption, science and theology, and questions about biblical authority. My discussion in this article purposefully discusses questions with the context of Evangelicalism strongly in view, without 
for that reason suggesting that it is necessarily something wrong with the approach of Lutheran theologians (often situated in a European context) framing the discussion in another way. But the discussions in this article are relevant also Lutheran contexts because it concerns new scientific findings that has a bearing on what are the possible alternatives in this part of the science-theology discussion. An earlier version of a similar discussion is the back-and-forth debate between Per Lønning and Anders J. Bjørndalen in the Norwegian journal Tidsskrift for teologi og kirke in 1966. The most significant changes of premises in their discussion contra today, is new developments in genetics and OT hermeneutics and source criticism.

23 Venema in Adam and the Genome, 4 and 55. My emphasis. In the words of his co-author Scot McKnight: 'that you and I, and the rest of humans for all time, come from two solitary individuals, Adam and Eve[:] Genetics make that claim impossible' (xi). My emphasis. Collins puts the point a little more carefully: 'it has become common among geneticists to infer not only that humans share common ancestry with the apes but also that the initial human population is much larger than two.' Collins, Reading Genesis Well, 232. A popular account of recent mainstream genetical research can be found in Adam Rutherford, A Brief History of Everyone Who Ever Lived: The Stories In Our Genes (London: Orion Publishing co. 2016). Also available in U.S. version: A Brief History of Everyone Who Ever Lived: The Human Story Retold Through Our Genes. New York: The Experiment, 2017.

24 The discussion leading to this conclusion happened mainly in a mile-long discussion thread at Biologos forum: https://discourse.biologos.org/t/adam-eve-and-population-genetics-a-reply-to-dr-richard-buggs-part1/37039/1064 (accessed March 4, 2019). Venema sums up his view in the podcast available at https://www.apologeticscanada.com/2018/11/30/adam-and-eve-and-the-human-genome-an-interview-withdennis-venema/ (from about 29:50; accessed March 3, 2019).

25 These are not humans in the sense applied by Venema in the book, equaling anatomically modern human beings, possibly appearing as far back as about 300000 years ago. It is notoriously difficult to define the boundary between human and non-human in this context, specially scientifically (because all species boundaries in evolutionary history are more or less arbitrary dividing lines through gradient changes), but also theologically (where to draw the line between humans and hominins, why and with what consequences). 26 Again at https://discourse.biologos.org/t/adam-eve-and-population-genetics-a-reply-to-dr-richard-buggspart-1/37039/1064.

27 Ian McFarland, In Adam's fall: A Meditation on the Christian Doctrine of Original Sin (Chichester: Wiley-Blackwell, 2010), 143. The words are used with reference to the passages from Augustine discussed above in a footnote. McFarland does not claim that this is Augustine's view of the concrete matter, but tries to apply Augustine's hermeneutical criteria to the scientific situation today, which Augustine for obvious reasons could not. In the context McFarland also includes issues about evolutionary theodicy. I do not have space to go into that question in this article. Attempts at that can be found in Christopher Southgate, The Groaning of Creation: God, Evolution and the Problem of Evil (Louisville: Westminster John Knox Press, 2008), or in Asle Eikrem and Atle Ottesen Søvik, 'Evolutionary theodicies - an attempt to overcome some impasses', Neue Zeitschrift für Systematiche Theologie und Religionsphilosophie, 3, (2018:) 428-434, preprint available at https://atleottesensovik.mf.no/Filer/Publikasjoner\%20før\%202018/Evolutionary\%20theodicies\%20preprint.pdf (accessed March 8, 2019).

28 A good description of this task is found in William T. Cavanaugh \& James K. A. Smith, 'Introduction: Beyond Galileo to Chalcedon', in Evolution and the Fall (Grand Rapids: Eerdmans, 2017). They summarize: 'the church will have to collectively discern what constitutes a faithful extension of the tradition. Perhaps we might determine that the picture of a historical couple lapsing in a single episode is not essential. But we might also discern that making fallenness basically synonymous with finitude violates the 'core' of the traditional doctrine,' p. xxv. Cf. a similar understanding of this theological task in Nicholas Olkovich, 'Reinterpreting Original Sin: Integrating Insights From Sociology and the Evolutionary Sciences,' The Heythrop Journal, LIV (2013): 715-731.

29 This is the main approach taken in Patricia A. Williams, Doing without Adam and Eve: Sociobiology and Original Sin (Minneapolis: Fortress Press, 2001). A similar account to mine so far of the history of traditional narratives, their problems and the possible paths forward can be found in Wiley, Original Sin, 1 and passim, cf. also Conradie, Redeeming Sin, 131. Wiley, however, rejects the historicity of traditional narratives of Adam and Eve, and constructs a doctrine of original sin that is grounded (only) in an analysis of the present human situation as sustained inauthenticity, drawing especially on Bernhard Lonergan (see ch. 8). Thus she is not much interested in the question put in the way I do in this article.

30 As Dietrich Bonhoeffer puts it, '[the church] views the creation from Christ; or better, in the fallen, old world it believes in the world of the new creation, the new world of the beginning and end, because it believes in Christ and nothing else.' Creation and Fall: A Theological Exposition of Genesis 1-3. Dietrich Bonhoeffer Works, vol. 3. (Minneapolis: Fortress Press, 1997), 22 (the volume is a transcript of Bonhoeffer's lectures at the University of Berlin, 1932-33). Already the Church Father Ireneus (ca. 200 AD) suggested that it is Adam that is modelled on Christ, not the other way around, se Bouteneff, Beginnings, 81-82. 
31 See T. A. Noble, 'Original Sin and the Fall: Definitions and A Proposal,' in R. J. Berry and T.A. Noble, eds. Darwin, Creation and the Fall: Theological Challenges (Nottingham: Apollos/InterVarsity Press, 2009), 112-113.

32 That this is a basic insight in the doctrine of sin is emphasized e.g. by Jan-Olav Henriksen (referring to John Haught), in Life, Love and Hope: God and Human Experience (Grand Rapids: Eerdmans 2014), 262-3n49; and Conradie, Redeeming Sin, 76 and passim.

33 This is almost surely the better interpretation of the Greek phrase eph' ho in Rom 5:12: not that everybody sinned 'in' that one human being (so Augustine and many other Latin writers, following the Latin Vulgate translation), but that all are sinners subject to death 'because' they (like that one human being) have all sinned themselves. See e.g. McKnight in Adam and the Genome, 173; 184-188.

34 Bonhoeffer, Creation and Fall, 105.

35 This is a central claim in the theodicy developed by Atle Ottesen Søvik. Se The Problem of Evil and the Power of God (Leiden: Brill, 2011) and later works.

36 Cf. Bonhoeffer, Creation and Fall, 139.

37 As Collins, Reading Genesis Well, 229, points out, the expression might well be an allusion to or an echo of Wisdom of Salomon 2:23-24.

38 Cf. The 5-model list presented in Bjørn Are Davidsen and Atle Ottesen Søvik, Evolusjon eller kristen tro? - Ja takk, begge deler!: Om fornuft, vitenskap og tro, De store spørsmålene \#2 (Follese: Efrem forlag, 2016), $167-168$, can serve as a reminder that there are other legitimate ways of mapping the alternatives and framing this discussion. Other mappings of alternatives can be found in C. John Collins, Did Adam and Eve Really Exist? Who They Were and Why You Should Care (Wheaton: Crossway, 2011), and Denis Alexander, Creation or Evolution: Do We Have to Choose? Second edition (Oxford: Lion Hudson, 2014), chapters 10 and 12 .

39 Most thoroughly in Kirkegaard alias Vigilius Haufniensis, The Concept of Anxiety. There is also relevant material in Kierkegaard alias Anti-Climacus, The Sickness Unto Death. For reasons of space I am not able to go into a substantial discussion about Kierkegaard's position here, and only refer to him through secondary literature. For discussions of Kierkegaard's view see McFarland, In Adam's Fall, 43-44 and Knut Alfsvåg, Christology as Critique: On the Relation between Christ, Creation and Epistemology (Eugene: Pickwick Publications, 2018), 135-145.

40 See Bonhoeffer, Creation and Fall. Aaron Riches expresses a similar position in 'The Mystery of Adam: A Poetic Apology for the Traditional Doctrine' in Evolution and the Falln, ed. James K. A. Smith and William T. Cavanaugh eds., Evolution and the Fall (Grand Rapids: Eerdmans, 2017). Riches says that Adam 'is the first being of human history', but because he is proto-logical, part of proto-history he 'cannot be investigated by historical methods' (p. 123). It sounds a bit incredible to me that something historical cannot be investigated by historical methods.

41 In the words of Conradie: 'To err may be human, but if sin is 'natural,' then the contingency of sin and salvation can no longer be maintained.' Redeeming Sin, 97, cf. 110, and 133: '..even if the fall is regarded as a myth, such a myth needs to help one to make sense of where and how things have gone wrong. (...)

The question of plausibility [..] cannot be avoided unless one wishes to argue that nothing has gone wrong, or that things have always been wrong and that there is no specific human culpability for what has gone wrong.' And further: 'The postulate of a historical fall is therefore, it seems to me, an essential requirement for (an Augustinian understanding of) the Christian faith, even if the fall as a historical event can no longer be located in the Eden narrative, interpreted as literal history' (p. 135). Similarly George L. Murphy, 'Roads to Paradise and Perdition: Christ, Evolution, and Original Sin,' Perspectives on Science and Faith, 58, 2 (June 2006): 112, says: 'the claim that Adam is not a historical individual in the modern sense does not mean that Paul is talking only about the existential situation of all people, or that the origin of sin is not in view in the text [Rom 5].'

42 Young Earth Creationism is similar to this type, but with another timeframe, because it has not the same need of making Scripture and contemporary science say the same thing.

43 Cf. the discussion between Dennis Venema and Richard Buggs referred to above.

44 A recent example of this type of view is found in Hössjer, Ola, Ann K. Gauger and Colin R. Reeves, 'An Alternative Population Genetics Model,' in Theistic Evolution: A Scientific, Philosophical, and Theological Critique, ed. J. P. Moreland et. al. (Wheaton: Crossway, 2017), 503-521.

45 This will often mean about 6-10-12 000 years ago, referring to the context and/or chronology of Genesis, but other timeframes are also possible.

46 'Some kind of historicity' here includes ideas from Adam and Eve as concrete individual human beings, to notions of the text as figurative or using pictures, but 'there are actual events that the pictures refer to' C. John Collins, 'Adam as Federal Head of Humankind,' in general ed. Stanley P. Rosenberg ed. Finding Ourselves After Darwin: Conversations on the Image of God, Original Sin, and the Problem of Evil, general ed. Stanley P. Rosenberg (Grand Rapids: Baker Academic, 2018), 151. 
47 E.g. in John Stott, Understanding the Bible, Expanded edition (Grand Rapids: Zondervan, 1984), 55-56. A more recent adherent is Tim Keller, e.g. in this Gospel Coalition video: https://www.thegospelcoalition.org/article/keller-moore-duncan-non-negotiable-beliefs-about-creation/ (accessible 29.09.2019).

48 Most thoroughly in Swamidass, Genealogical Adam and Eve, which collects and develops several earlier articles and posts from his blog Peaceful Science (see the bibliography of the book for details). Although it is genetically possible that all human beings share common ancestors in this genealogical sense, it is almost impossible that we do so in only one couple, it is more likely the case that we all are related through several couples at different points in history (this also holds for models adhering to mainstream population genetics). Adam and Eve is thus of theological significance only, not having any kind of scientific impact or plausibility beyond them being (probably) possible at a date and place close to the Genesis narrative.

49 That may be taken as a deviation from the literal sense of 1 Cor 15:45, saying that Adam was the first human being (anthropos).

50 For an explanation of the term, see Swamidass, Genealogical Adam and Eve, 130. He later (133-135) makes a distinction between those people as biological humans, while the lineage of Adam and Eve are also textual humans (those who are of real concern in the biblical text).

51 C. John Collins, 'Adam as Federal Head', 158.

52 Cf. The discussion of the passage in Collins, Reading Genesis Well, 230-1. Collins may be making much of little evidence; putting too much weight on biblical theology and less on linguistics and historical hermeneutics.

53 See Smith, 'What Stands on the Fall?: A Philosophical Exploration,' in Evolution and the Fall, ed. James K. A. Smith and William T. Cavanaugh eds., Evolution and the Fall (Grand Rapids: Eerdmans, 2017), esp. 61-62. Similar reasoning from a Catholic perspective can be found in Murphy, 'Roads to Paradise and Perdition,' 115-116, and from a Lutheran perspective in Robert Jenson, Systematic Theology: The Works of God, vol. II (Oxford University Press, 1999), 150.

54 Conradie, Redeeming Sin. Per Lønning argued something similar in his contributions in Tidsskrift for teologi og kirke (TTK), 1966. Lønning's position also has elements of type one in it. Joel B. Green, “Adam, What Have You Done?': New Testament Voices on Original Sin,' in Evolution and the Fall, ed. William B. Cavanaugh and James K. A. Smith eds., Evolution and the Fall, (Grand Rapids: Eerdmans, 2017) argues that such a scenario is also reconcilable with NT view on original sin.

55 This point is well put by Greg Cootsona in a discussion forum with Swamidass on the web: 'Stated another way, the only reason that we are concerned with this original pair living in Mesopotamia around 6,000-10,000 is our biblical and theological tradition,' from

https://discourse.peacefulscience.org/t/greg-cootsona-mere-science-and-adams-empty-chair/591/18 (accessed March 4, 2019, my emphasis). Swamidass confirms this indirectly in his book by granting the claims of biblical inerrancy of the Chicago Statement and the Lausanne covenant as given presuppositions (without discussion or justification) for his theological working space in dialogue with science. The question of warrant for belief in Adam and Eve turns on (almost only) 'whether we think Scripture is trustworthy, and what we think it is telling us', Genealogical Adam and Eve, 87.

56 These passages include Matt 19:4-5; Luk 3:38; Rom 5:12.14; 1 Cor 15:45; 1 Tim 2:13. An important path that I'm not able to follow at any length here due to space considerations, is whether a traditional reading of these passages are sensitive enough to the Adams and Eves of the Second Temple Judaism context. It is perhaps not totally obvious that Adam as historical person in something close to a modern sense is the only viable interpretation of these passages. See e.g. McKnight's part of Adam and the Genome; Green, “Adam, What Have You Done?", 98-105; Antti Laato and Lotta Valve eds. Adam and Eve Story: In the Hebrew Bible and in Ancient Jewish Writings Including the New Testament. Studies in the Reception History of the Bible, 7, ed. Antti Laato and Lotta Valve (Turku: Åbo Akademi University \& Winona Lake: Eisenbrauns, 2016). As the commentaries show, there is a range of available interpretations of each of the mentioned texts. I cannot go into the details of them here, but I think that the conclusion I draw from the sum of these texts is a straightforward one.

57 Cf. the scene in the 2014 Hollywood film Noab where Adam and Eve has skin shining as from gold. Although I do not suggest that the film is fully representative to the tradition or that this is a plausible interpretation of what Genesis is saying, I think the scene captures important intuitions in traditional narratives about Adam and Eve that are very hard to integrate in a type three view.

58 This point was made by Venema vs. Swamidass at an Adam and the Genome book symposium, see http://henrycenter.tiu.edu/2017/07/response-to-the-symposium-part-1/ (accessed March 4, 2019). A theory of common human descent much more easily goes together with an insistence that all human beings are part of the same 'family'. Swamidass has answered any accusations of implicit racism in his book Genealogical Adam and Eve, granting 'people outside the Garden' full human dignity and rights, even perhaps the image of God. But it remains strange that his distinction between biological humans and textual (biblical, in the 1 ineage of Adam) humans must mean that not all humans were humans in the same sense for quite a considerable time before Adam and Eve's lineage spread throughout the world. In his version of a regional Noahic 
Flood (not literally global as stated in Gen 7:19-20) restricting the Adam and Eve textual human lineage down to 5, it also seems strange that God will have to be punishing people originating outside the Garden together with textual humans for the sins committed by textual humans.

59 See Domning, Daryl P. and Monika K. Hellwig, Original Selfishness: Original Sin and Evil in the Light of Evolution (New York: Routledge, 2006), 136.

60 Swamidass, Genealogical Adam and Eve, 146 tries to counter this objection by saying that Gen 2 refers to a specific place, but the creation of man/Adam happens before the Garden is set up, and v. 4 clearly states that the whole world is within view.

61 A similar judgment is made by Greg Cootsona in his book Mere Science and Christian Faith: Bridging the Divide with Emerging Adults (Downers Grove: InterVarsity Press, 2018) and in this forum discussion: https://discourse.peacefulscience.org/t/greg-cootsona-mere-science-and-adams-empty-chair/591 (accessed March 4, 2019).

62 I have reviewed the book at http://readingreligion.org/books/redeeming-sin (accessedible March 8, 2019).

63 Conradie, Redeeming Sin, 196.

64 On Irenaeus theology of creation - and fall - see Matthew Craig Stenberg, Irenaeus on Creation: The Cosmic Christ and the Saga of Redemption. Supplements to Vigiliae Christianae vol. 91 (Leiden/Boston: Brill, 2008).

65 Chapman, 'Hominid Failings: An Evolutionary Basis for Sin in Individuals and Corporations,' in Evolution and Ethics: Human Morality in Biological and Religious Perspective, ed. Philip Clayton and Jeff Schloss (Grand Rapids/Cambridge: Eerdmans), 109. Chapman later adds that still 'evolutionary theory does not actually support the reduction to deterministic, gene-based explanations' (p. 111). On this point see also Conradie, Redeeming Sin, 91-92; 131-143.

66 See Conradie, Redeeming Sin, 140 for further details. The God-relation of the first human beings/sinners is often a central element in type three views, see e.g. Smith, 'What Stands on the Fall,' 59. While it is possible that the creatures first identifiable as humans were addressed by God with a special kind of revelation, I do not think that is a necessary inference from the Genesis narrative read in a type four way. The revelation starting a new kind of relationship between creatures and God at the dawn of humanity might as well be conceived as a part of 'natural' as of 'special' revelation (to use common terms of Scandinavian Lutheran theology).

67 See Paul M. Blowers and Robert Louis Wilken, ed./trans. On the Cosmic Mystery of Jesus Christ: Selected Writings from St. Maximus the Confessor (New York: Yonkers/St. Vladimir's Seminary Press, 2004), 24. I was made aware of this point through working with a Master's thesis in Greek several years ago, see Gunnar Innerdal, Maximos Bekjenneren: En bok om askese. Oversettelse, innledning og noter (University of Bergen, fall 2010), 100.

68 The relevant texts from Maximus are Ambiguum 42, (Quaestiones) Ad Thallasium 61, cf. Ad Thal. 1. Translation of these are available in Blowers/Wilken, On the Cosmic Mystery, 85; 97; 131. Bouteneff, Beginnings, 121-168 cites the Cappadocians as being very unsure about the character (and perhaps existence) of paradise.

69 Cavanaugh and Smith, 'Introduction,' xxvi. The expressions are used in a summary of Smith's article later in the volume.

70 Noble, 'Original Sin and the Fall,' 114. The same presupposition is made by Swamidass, Genealogical Adam and Eve, 184, speaking of the Fall as a 'single act'.

71 '. .has there not always been an unexamined assumption here: namely, that the universality and the moral character of original sin both necessarily stem form one and the same individual, act, and moment in time?' (not to mention that in the Genesis narrative it is not an individual, but a couple acting...!), Domning and Hellwig, Original Selfishness, 140.

72 See Paul Ricoeur, The Symbolism of Evil, translated by Emerson Buchanan (Boston: Beacon Press, 1969), 243.

73 Cf. McFarland, In Adam's Fall, 160: “Adam' can only be regarded as the first in a series of sinners and not as the unique 'cause' of subsequent human sin.' '...we are all one with Adam, and thus we share with him - and with each other - the same nature, marked by the damaged wills that turns us all invariably and catastrophically away from God.'

74 Cf. Conradie, Redeeming Sin, 217.

75 See e.g. Murphy, 'Roads to Paradise and Perdition', 112 for a short but informed account of this way of thinking. A much read and controversial work on these questions from an Evangelical point of view is Kenton Sparks, God's Word in Human Words: An Evangelical Appreciation of Critical Biblical Scholarship (Grand Rapids: Baker Academic, 2008). Swamidass, Genealogical Adam and Eve, 139 suggests a similar hermeneutic concerning some sayings in Scripture (e.g. 'to the ends of the earth', and a regional, not global Noahic flood), but for some unstated reason it is not an alternative for the biblical passages supposed to be claiming what he adheres to as must-be historical givens concerning Adam and Eve and universal ancestry through them. 
76 On 1 Cor 11, cf. how parts of this text are 'relativized' historically as early as in the Augsburg Confession, art. XXVIII, along with the prohibition of eating blood in contexts with Jewish presence from Acts 15 .

77 McKnight in Adam and the Genome, 189.

78 The concept 'theoretical framework' in relation to truth value is worked out in detail by the German philosopher Lorenz B. Puntel and his American friend and colleague Alan White. See Puntel and White (trans.), Structure and Being: A Theoretical Framework for a Systematic Philosophy (University Park: Pennsylvania State University Press, 2008), and Alan White, Toward a Philosophical Theory of Everything: Contributions to the Structural-Systematic Philosophy (New York: Bloomsbury, 2014).

79 McKnight in Adam and the Genome, 187.

80 Collins, for example admits that '[p]robably there are some scientific problems' with his type three view, see 'Adam as Federal Head of Humankind', 158.

81 An earlier version of this work was presented at the Veritas Research Symposium, NLA University College, Gimlekollen, 19.10.18, and some of the material in a different set up at a research seminar at two day-meeting of Department of Theology, Religion and Philosophy, NLA University College, 05.02.2018. I have also discussed the material with prof. Neil Messer, University of Winchester, and received extensive editorial feedback from Theofilos. I want to express thanks to my colleagues for the responses and input received. 